\title{
27. SILICOFLAGELLATE AND COCCOLITH STRATIGRAPHY, NORWEGIAN-GREENLAND SEA, DEEP SEA DRILLING PROJECT LEG 38
}

\author{
David Bukry, United States Geological Survey, La Jolla, California
}

\section{INTRODUCTION}

Leg 38 of the Deep Sea Drilling Project, recovered 354 cores at 16 drilling sites, Sites $336-350$ and 352 . Light-microscope techniques (Bukry, 1975) were used to study the silicoflagellates and coccoliths of 140 samples from these cores. The present study is largely devoted to the diverse silicoflagellate assemblages of Eocene to Miocene age.

\section{ZONATION}

A paucity of low-latitude biostratigraphic marker coccoliths in the fossil assemblages of Leg 38, together with the low diversity of the assemblages, limits the usefulness of coccoliths for zonation.

Silicoflagellate biostratigraphic determinations for Leg 38 incorporate the work of Ling (1972), Ciesielski (1975), and Perch-Nielsen (1975, 1976). Zonal names are from Bukry (1975) and Perch-Nielsen (1976). The possibility of establishing a bipolar synthesized zonation is indicated by initial studies of Leg 38 cores, but exacting taxonomic comparisons of actual specimens between the assemblages of DSDP Legs 38, 36, 35, 29, and 28 need to be made. This would help to determine what parts of several finely divided, high-latitude, local zonal sequences (Martini 1972, 1974; Perch-Nielsen, 1975, 1976; Ciesielski, 1975) can be applied on a transoceanic basis and, perhaps, what new units may be defined as refinement of species concepts continues.

Changes in the relative abundances of taxa and minor changes in their form from one region to another may appear to suggest numerous different zonations. Evolutionary lineages in some major genera (Corbisema and Naviculopsis), however, provide a fairly consistent taxonomic and stratigraphic basis with which to assess the more variable (polyphyletic or strongly ecologically controlled) taxa of genera such as Dictyocha, Distephanus, and Mesocena.

Populations of Naviculopsis foliacea s. str. and $N$. navicula s. str. have generally well known and limited ranges and are key biostratigraphic markers (Ling, 1972; Martini, 1972, 1974). But, species such as Distephanus crux crux s. ampl. and Mesocena diodon or M. elliptica s. ampl. have recurrent local acmes through the upper Paleogene and Neogene. For example, the coexistence of Corbisema triacantha, Naviculopsis navicula, and $N$. quadrata in Sample GSCG-466CC, from the Southern California Borderland, determines an early Miocene age (Sanfilippo et al., 1973), but the same sample contains significant numbers of $M$. diodon and $M$. elliptica, which are used as guide fossils for younger stratigraphic horizons. Some regional differences in the assemblages of the Naviculopsis quadrata Zone of Leg 38 and other areas are summarized in Table 1.

\section{SITE SUMMARIES}

\section{Site 336 (lat $63^{\circ} 21.06^{\prime} \mathrm{N}$, long $7^{\circ} 47.27^{\prime} \mathrm{W}$, depth $811 \mathrm{~m}$ )}

Except for two, sparse, Quaternary coccolith assemblages in Cores 1 and 5, no coccoliths or silicoflagellates were observed in deeper cores (Cores 27 to 36) at Site 336. The assemblages of Cores $1(4 \mathrm{~m})$ and $5(39 \mathrm{~m})$ are characterized by Quaternary Gephyrocapsa caribbeanica and many reworked Cretaceous taxa, such as Eiffellithus turriseiffeli and Micula decussata.

Site 337 (lat $64^{\circ} 52.30^{\prime} \mathrm{N}$, long $5^{\circ} \mathbf{2 0 . 5 1}$ 'W, depth $2631 \mathrm{~m}$ )

Four of seven samples from Site 337 in the Norway Basin contain coccoliths or silicoflagellates. Core 1 (8 $\mathrm{m})$ has an abundant Quaternary assemblage of Cyclococcolithina leptopora, Emiliania sp. cf. E. annula, E. ovata, G. caribbeanica, and Helicopontosphaera kamptneri; Cretaceous (Watznaueria barnesae) and Eocene or Oligocene (Reticulojenestra umbilica) reworked taxa are present. Silicoflagellate assemblages from Cores 9 and 10 (Table 2) are characterized stratigraphically by Corbisema flexuosa, C. katharinae, and Dictyocha aspera martinii which coexist in the late Eocene of the Southern Ocean (Perch-Nielsen, 1975; Bukry, 1975). A late Eocene or Oligocene age is suggested because of the low diversity of the assemblage and the absence of other Eocene guide species.

Site 338 (lat $67^{\circ} 47.11^{\prime} \mathrm{N}$, long $5^{\circ} 23.26$ ' , depth $1297 \mathrm{~m}$ )

Quaternary coccolith assemblages, including Coccolithus pliopelagicus and Gephyrocapsa caribbeanica, together with reworked Cretaceous and Paleogene taxa, are present in samples from Cores 1 to 5 ( 0 to $48 \mathrm{~m}$ ). Coccoliths are absent from Cores 6 to 19 (48 to $190 \mathrm{~m}$ ). An upper Oligocene assemblage in Sample 338-20-3, $30-31 \mathrm{~cm}(192 \mathrm{~m})$ contains Chiasmolithus altus, Coccolithus pelagicus, Cyclicargolithus abisectus, $C$. floridanus, Dictyococcites bisectus, Discoaster deflandrei, Discolithina spp., Helicopontosphaera euphratis, and Reticulofenestra sp. (small). Similar low-diversity assemblages of late Oligocene age, based on the coexistence of $C$. abisectus and D. bisectus, are present in Cores 22 to 24 ( 209 to $238 \mathrm{~m}$ ). The cool-water aspect of the assemblages is seen in the predominance of placoliths and the rarity or absence of discoasters and sphenoliths.

The next deepest coccolith-bearing sample available, 338-33-6, 90-91 cm (322 m), contains a provincial lower Eocene Tribrachiatus orthostylus Zone assemblage that has been encountered previously in the London Clay in England and from North Atlantic cores (see Site 343 
TABLE 1

Comparison of Lower Miocene Naviculopsis quadrata Zone Silicoflagellate Assemblages

\begin{tabular}{|c|c|c|c|c|c|c|c|}
\hline & Sample & $\begin{array}{l}\text { Depth } \\
\text { (m) }\end{array}$ & 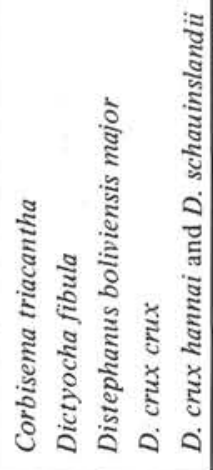 & 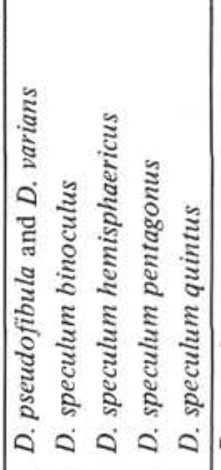 & 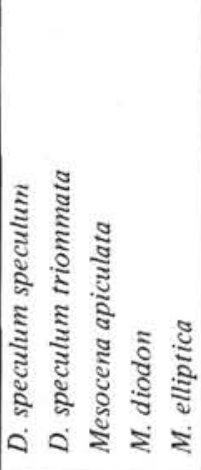 & 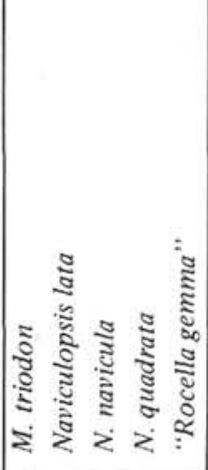 & 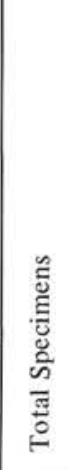 \\
\hline \multirow{2}{*}{$\begin{array}{l}\text { Pacific } \\
\text { Region }\end{array}$} & GSCG-466CC & 0.1 & 22 & $<1<1$ & $\begin{array}{lllll}1 & 3 & 1 & 19 & 4\end{array}$ & $\begin{array}{llll}12 & 1 & 1 & 32\end{array}$ & 300 \\
\hline & $\begin{array}{l}278-26-6, \\
75 \mathrm{~cm}\end{array}$ & 337 & $\begin{array}{lll}1 & 159\end{array}$ & 28 & $29 \quad 25$ & 36 & 100 \\
\hline $\begin{array}{l}\text { Leg } \\
38\end{array}$ & $\begin{array}{l}338-14-3 \\
40-41 \mathrm{~cm}\end{array}$ & 136 & $4<1<1 \quad 46 \quad 5$ & $\begin{array}{lll}1 & 3 & 14\end{array}$ & $\begin{array}{lll}3 & 3 & 5\end{array}$ & 1410 & 300 \\
\hline
\end{tabular}

Note: Taxa are recorded in percent. Sample GSCG-466CC from the Southern California Borderland (lat $120^{\circ} 28^{\prime} \mathrm{W}$, long $33^{\circ} 14^{\prime} \mathrm{N}$ ) also contains coccoliths of the Sphenolithus belemnos Zone.

TABLE 2

Silicoflagellates in Upper Eocene or Oligocene Samples from Site 337 Recorded in Percent

\begin{tabular}{|c|c|c|c|c|c|c|c|c|c|c|c|c|}
\hline $\begin{array}{c}\text { Sample } \\
\text { (Interval } \\
\text { in } \mathrm{cm} \text { ) }\end{array}$ & $\begin{array}{c}\text { Depth } \\
\text { (m) }\end{array}$ & 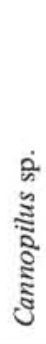 & 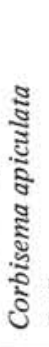 & $\underset{ن}{\stackrel{0}{3}}$ & 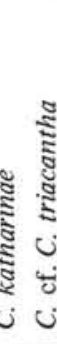 & 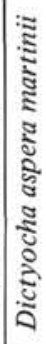 & 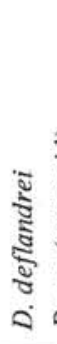 & 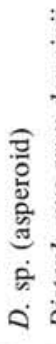 & 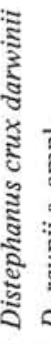 & 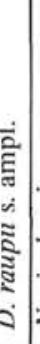 & 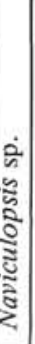 & 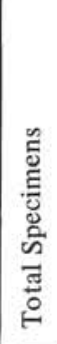 \\
\hline $337-9-6,80-81$ & 83 & 1 & & 612 & 241 & 8 & & 1 & & 3 & 1 & 100 \\
\hline $337-10-3,60-61$ & 89 & & & 44 & 81 & 6 & & 7 & & 34 & & 100 \\
\hline $337-10-6,62-64$ & 93 & 3 & 1 & 22 & $\begin{array}{ll}5 & 1\end{array}$ & 9 & 1 & 17 & 14 & 43 & & 200 \\
\hline
\end{tabular}

summary). Species present include: Coccolithus pelagicus s. ampl., Cyclococcolithina sp. aff. C. luminis, Discolithina sp. cf. D. pectinatus, Imperiaster obscurus, I. sp. aff. I. obscurus (quadrate), Transversopontis pulcher, Zygolithus dubius, and Z. protenus.

Silicoflagellates of late Oligocene to middle Miocene age are common in Cores 8 to 23 (76 to $228 \mathrm{~m}$ ). Species of Distephanus numerically dominate most of the samples (Table 3). Several taxa from upper Oligocene Cores 20 to 23, Distephanus crux darwinii and D. raupii, are considered to be conspecific with coeval forms described from the upper Oligocene of DSDP Leg 36 in the South Atlantic Ocean. Many of the specimens, however, appear to be variants and are tabulated as compared species of D. crux crux and D. crux darwinii. Additional study is needed to distinguish significant cosmopolitan evolutionary populations from local variant populations.

Pseudorocella corona, a problematic silicoflagellate, is present within the lower Miocene range of Naviculop- sis quadrata at Site 338; this is similar to its occurrence at the top of the $N$. quadrata Zone at Site 278 in the Antarctic (Bukry, 1975). The lower Miocene at Site 338 is identified by the overlapping ranges of $N$. lata, $N$. navicula, and N. quadrata; Corbisema triacantha is virtually absent in younger samples. Sample 338-17-3, 40$41 \mathrm{~cm}(164 \mathrm{~m})$ from the lower Miocene is unusual in the presence of giant specimens of Dictyocha pentagona, Distephanus pseudofibula, and D. varians. The multiply-barred apical structures of these taxa suggest an affinity between them. This affinity is further emphasized here by their matching size and proportions.

The middle Miocene, characterized by the overlapping ranges of Distephanus sp. cf. D. longispinus, $D$. speculum hemisphaericus, and Mesocena apiculata $\mathrm{s}$. ampl., has an unusual abundance of Cannopilus ernestinae at the top of the section. C. ernestinae may be a bipolar marker species for the middle Miocene, because it is also present in the Antarctic in sediments of this age (see Site 348 summary). 
TABLE 3

Silicoflagellates from the Upper Oligocene to Middle Miocene at Site 338 Recorded in Percent

\begin{tabular}{|c|c|c|c|c|c|c|c|c|c|c|c|c|c|}
\hline Age & & ddle $N$ & iocene & & & Early & Mioc & & & & & $\begin{array}{l}\text { Late } \\
\text { igocen }\end{array}$ & \\
\hline Depth $(m)$ & 79 & 86 & 97 & 116 & 126 & 136 & 146 & 164 & 174 & 183 & 192 & 212 & 228 \\
\hline Species & $\begin{array}{l}\overrightarrow{0} \\
\overline{0} \\
0 \\
0 \\
\infty \\
\infty \\
\infty \\
\infty \\
\infty \\
m\end{array}$ & 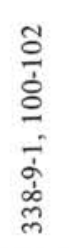 & 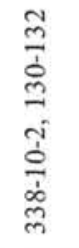 & 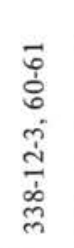 & 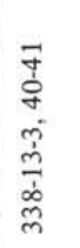 & $\begin{array}{l}\vec{y} \\
\dot{+} \\
\dot{m} \\
\dot{I} \\
\frac{1}{0} \\
m \\
m\end{array}$ & $\begin{array}{l}\vec{y} \\
\dot{+} \\
\dot{n} \\
\dot{n} \\
\dot{m} \\
m\end{array}$ & 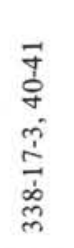 & 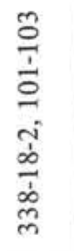 & 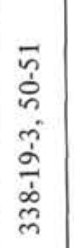 & 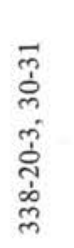 & 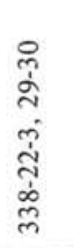 & 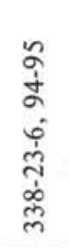 \\
\hline $\begin{array}{l}\text { Cannopilus ernestinae } \\
\text { C. cf. C. picassoi } \\
\text { C. cf. C. schulzii } \\
\text { Corbisema archangelskiana } \\
\text { C. flexuosa and cf. }\end{array}$ & 18 & $\begin{array}{l}2 \\
1 \\
2\end{array}$ & $<1$ & & & & 1 & 1 & 1 & 12 & $<1$ & & 1 \\
\hline $\begin{array}{l}\text { C. triacantha and cf. } \\
\text { Dictyocha aff. D. aspera clinata } \\
\text { D. cf. D. deflandrei } \\
\text { D. fibula } \\
\text { D. pentagona (large) }\end{array}$ & 1 & & & & $\begin{array}{r}3 \\
1 \\
<1 \\
\end{array}$ & $\begin{array}{r} \\
\quad 4 \\
<1\end{array}$ & $<1$ & $\begin{array}{l}<1 \\
14\end{array}$ & 2 & 50 & 1 & 1 & \\
\hline $\begin{array}{l}\text { D. pulchella } \\
\text { D. sp. (fibuloid) } \\
\text { Distephanus boliviensis boliviensis } \\
\text { D. boliviensis major } \\
\text { D. crux crux s. ampl. }\end{array}$ & 18 & $\begin{array}{r}1 \\
21\end{array}$ & $\begin{array}{r}17 \\
4 \\
33\end{array}$ & 55 & 52 & $\begin{array}{l}<1 \\
46\end{array}$ & 42 & $\begin{array}{r}1 \\
1 \\
1 \\
11\end{array}$ & 6 & 21 & $\begin{array}{r}<1 \\
5\end{array}$ & & \\
\hline $\begin{array}{l}\text { D. aff. D. crux crux (1) } \\
D . \text { aff. D. crux crux (2) } \\
\text { D. crux darwinii } \\
D . \text { aff. D. crux darwinii } \\
\text { D. cf. D. longispinus }\end{array}$ & & 4 & 3 & 2 & & & & & $\begin{array}{r}12 \\
2\end{array}$ & & $\begin{array}{r}2 \\
86\end{array}$ & $\begin{array}{r}4 \\
17 \\
46 \\
29\end{array}$ & $\begin{array}{l}62 \\
22\end{array}$ \\
\hline $\begin{array}{l}\text { D. pseudofibula (large) } \\
\text { D. raupii } \\
\text { D. schauinslandii schauinslandii } \\
\text { D. schauinslandii stradneri } \\
\text { D. speculum binoculus }\end{array}$ & $\begin{array}{r}2 \\
16 \\
1\end{array}$ & $\begin{array}{r}25 \\
1\end{array}$ & $\begin{array}{l}1 \\
5\end{array}$ & $<1$ & 5 & 3 & $\begin{array}{l}7 \\
3 \\
4\end{array}$ & 3 & 29 & & 2 & 1 & 6 \\
\hline $\begin{array}{l}\text { D. speculum elongatus } \\
\text { D. speculum giganteus } \\
\text { D. speculum hemisphaericus } \\
\text { D. speculum minuta } \\
\text { D. speculum pentagonus }\end{array}$ & 1 & 1 & $\begin{array}{r}30 \\
2 \\
<1\end{array}$ & 12 & 15 & 14 & 13 & 1 & 8 & $\begin{array}{c}11 \\
1\end{array}$ & 2 & 1 & 1 \\
\hline $\begin{array}{l}\text { D. speculum pseudocrux } \\
\text { D. speculum quintus } \\
\text { D. speculum speculum } \\
\text { D. speculum triommata } \\
\text { D. cf. D. staurodon }\end{array}$ & 1 & 25 & 2 & $\begin{array}{r}3 \\
14\end{array}$ & $\begin{array}{l}2 \\
4\end{array}$ & $\begin{array}{r}<1 \\
3 \\
3\end{array}$ & $\begin{array}{l}4 \\
3\end{array}$ & $\begin{array}{r}1 \\
<1 \\
6 \\
13\end{array}$ & $\begin{array}{r}4 \\
4 \\
13\end{array}$ & 1 & & 1 & \\
\hline $\begin{array}{l}\text { D. varians (large) } \\
\text { Mesocena apiculata s. ampl. } \\
\text { M. diodon } \\
\text { M. triangula } \\
\text { Naviculopsis } \text { cf. } N \text {. biapiculata }\end{array}$ & $\begin{array}{r}34 \\
1\end{array}$ & $\begin{array}{r}1 \\
10\end{array}$ & 4 & 3 & $\begin{array}{l}1 \\
4\end{array}$ & $\begin{array}{l}1 \\
5\end{array}$ & $\begin{array}{l}1 \\
8\end{array}$ & 22 & 1 & 1 & $\begin{array}{r}2 \\
<1\end{array}$ & 1 & 8 \\
\hline $\begin{array}{l}\text { N. lata } \\
\text { N. lata (prolongate) } \\
N \text {. navicula } \\
\text { N. quadrata } \\
\text { Pseudorocella corona }\end{array}$ & 1 & & & & $\begin{array}{r}<1 \\
<1 \\
1 \\
9\end{array}$ & $\begin{array}{r}1 \\
4 \\
10\end{array}$ & $\begin{array}{l}1 \\
1 \\
3 \\
1 \\
1\end{array}$ & 2 & 16 & & & & \\
\hline Total specimens & 200 & 100 & 300 & 300 & 300 & 300 & 300 & 300 & 300 & 200 & 300 & 170 & 100 \\
\hline
\end{tabular}

\section{Site 339 (lat $67^{\circ} 12.65^{\prime} \mathrm{N}$, long $6^{\circ} 17.05^{\prime} \mathrm{E}$, depth $1262 \mathrm{~m}$ )}

All six samples examined from Site 339 contain coccoliths and silicoflagellates. The upper three samples of
Cores 1 to 8 ( 0 to $75 \mathrm{~m})$ contain common, but lowdiversity assemblages of Quaternary coccoliths, such as Coccolithus pelagicus, Crenalithus doronicoides, $C$. sp. cf. C. productellus, and Gephyrocapsa sp. cf. G. 
caribbeanica, admixed with reworked Cretaceous (Prediscosphaera cretacea and others) and Eocene (Zygolithus dubius and others). Silicoflagellate assemblages from Cores 7 to 12 (Table 4) are assigned to the middle or upper Eocene Dictyocha hexacantha Zone on the basis of the association of Dictyocha hexacantha, $D$. spinosa, Naviculopsis constricta, and $N$. foliacea.

\section{Site 340 (lat $67^{\circ} 12.47^{\prime} \mathrm{N}$, long $6^{\circ} 18.38^{\prime} \mathrm{E}$, depth $1217 \mathrm{~m}$ )}

All 11 samples examined from Site 340 contain coccoliths or silicoflagellates. As at other Leg 38 sites, the Quaternary coccolith assemblage of Core $1(3 \mathrm{~m})$ is admixed with common Cretaceous (Arkhangelskiella cymbiformis and others) and Eocene (Isthmolithus recurvus and others) reworked specimens. Eocene silicoflagellates, predominately of the genus Naviculopsis, are present in all 10 samples from Cores 2 to 11 ; four representative assemblages were counted (Table 5). Dictyocha hexacantha and D. spinosa are cosmopolitan indicators for the middle or upper Eocene Dictyocha hexacantha Zone (Bukry, 1975; Perch-Nielsen, 1976); however, the assemblages at Site 340 are provincial in character based on the common occurrence of Naviculopsis nordica, $N$. punctilia, and the presence of
Corbisema ovalis and Distephanus norvegiensis, all newly recognized taxa from the Norwegian-Greenland Sea (see section on Taxonomy). Most of the elements of the regional Naviculopsis vemae Zone and $N$. punctilia Zone of Perch-Nielsen (1976) are present, except for the marker species Naviculopsis vemae.

Site 341 (lat $67^{\circ} 20.10^{\prime} \mathrm{N}$, long $6^{\circ} 06.64^{\prime} \mathrm{E}$, depth $1439 \mathrm{~m}$ )

Although middle Miocene to Quaternary coccoliths are generally common in the 19 samples examined from Cores 1 to 32, diversity is so low that only broad age estimates are possible. Silicoflagellates are rare. Samples from Cores 1 to 5 ( 0 to $48 \mathrm{~m}$ ), assigned to the Quaternary, contain Gephyrocapsa caribbeanica and an abundance of reworked Cretaceous and Paleogene taxa. Cores 6 to 30 ( 48 to $418 \mathrm{~m}$ ) are assigned to the middle Miocene to Pliocene based on the occurrences of cosmopolitan species such as Cyclococcolithina macintyrei and Reticulofenestra pseudoumbilica. Reworked Cretaceous and Eocene taxa are common above Core 20, but rare below. The presence of Discoaster sp. cf. $D$. exilis and D. variabilis in Core $32(431 \mathrm{~m})$ indicates a probable middle Miocene age.

TABLE 4

Silicoflagellates in Middle or Upper Eocene Samples from Site 339 Recorded in Percent

\begin{tabular}{|c|c|c|c|c|c|c|c|c|c|}
\hline $\begin{array}{c}\text { Sample } \\
\text { (Interval in } \mathrm{cm} \text { ) }\end{array}$ & $\begin{array}{l}\text { Depth } \\
\text { (m) }\end{array}$ & 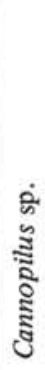 & 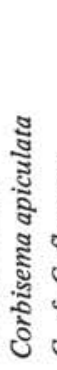 & 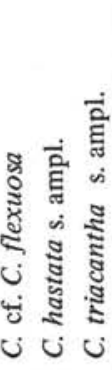 & 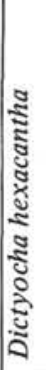 & 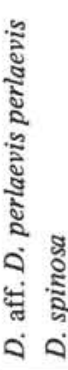 & 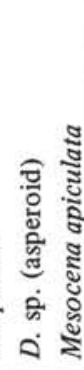 & 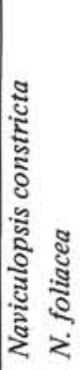 & 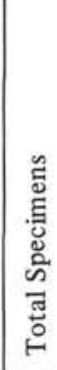 \\
\hline $339-7-3$ & 5 & & 9 & 2041 & 3 & 2 & 125 & 44 & 100 \\
\hline $339-10-3,40-41$ & 87 & 2 & 9 & 3928 & 2 & 21 & 112 & 4 & 100 \\
\hline $339-12-3,30-31$ & 105 & & & 24035 & 5 & & 101 & 2 & 100 \\
\hline
\end{tabular}

TABLE 5

Silicoflagellates in Middle or Upper Eocene Samples from Site 340 Recorded in Percent

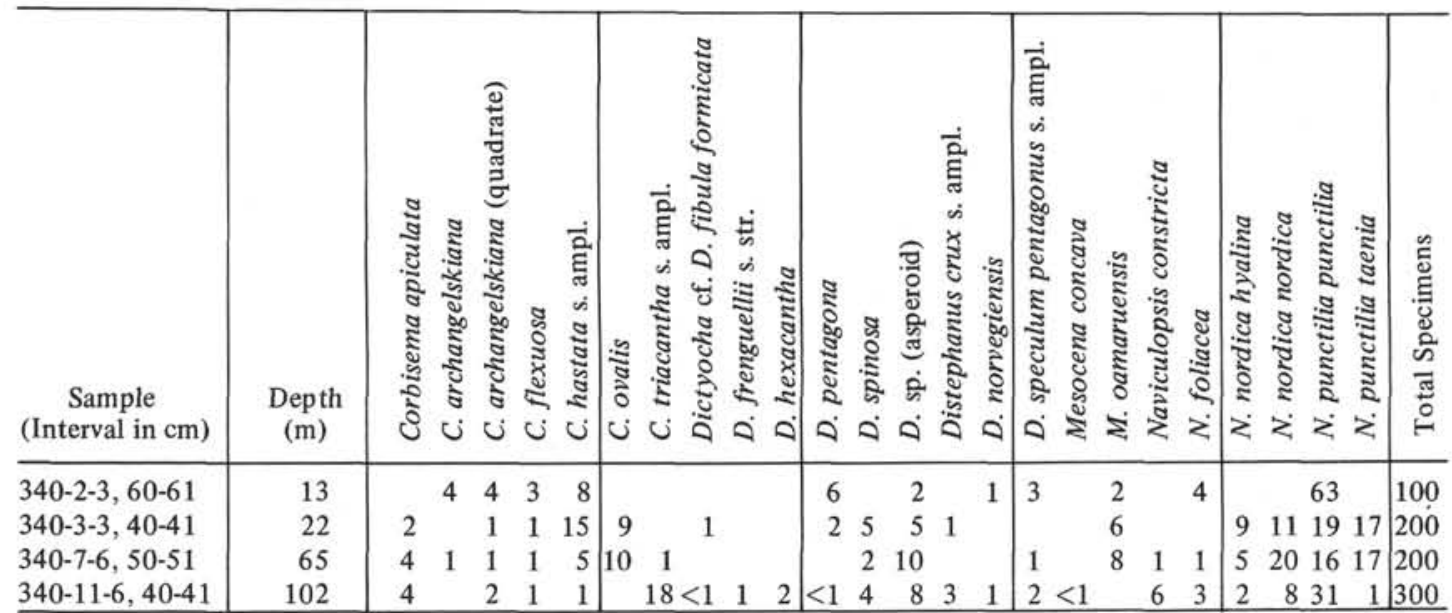


Site 342 (lat $67^{\circ} 57.04^{\prime} \mathrm{N}$, long $4^{\circ} 56.02^{\prime} \mathrm{E}$, depth $1303 \mathrm{~m}$ )

A Quaternary coccolith assemblage, including Coccolithus pelagicus, Crenalithus doronicoides, $C$. productellus, Gephyrocapsa caribbeanica, G. sp. cf. G. lumina, G. oceanica, Pontosphaera scutellum, and reworked Cretaceous specimens, is present in 342-1-6, $78-79 \mathrm{~cm}(7 \mathrm{~m})$ and is assigned to the Gephyrocapsa oceanica Zone.

Silicoflagellates are common and diverse in samples from Cores 5 and 6. A lower Miocene Naviculopsis quadrata Zone assemblage in Sample 342-6-3, 60-61 cm $(145 \mathrm{~m})$ contains the following percentages of taxa based on a count of 200 specimens: $32 \%$ Distephanus crux, $30 \%$ D. speculum hemisphaericus s. ampl., $11 \% D$. schauinslandii schauinslandii, 6\% Mesocena apiculata s. ampl., $5 \%$ Distephanus sp. cf. D. longispinus, $4 \%$ D. sp. aff. D. crux darwinii, 4\% Corbisema triacantha, $3 \%$ Naviculopsis quadrata, and $1 \%$ or $2 \%$ each of $N$. lata, $N$. navicula, $N$. ponticula, Distephanus speculum pentagonus, D. speculum speculum, D. varians (same large form as in Core 17, Site 338), and Corbisema flexuosa. The assemblage of Sample 342-5-6, 40-41 cm (140 m) lacks the early Miocene Naviculopsis and Corbisema and is assigned to the early middle Miocene on the basis of the predominance of Distephanus speculum hemisphaericus. Percentages of taxa, based on a count of 300 specimens, are $41 \%$ D. speculum hemisphaericus, $33 \%$ D. crux crux, $12 \%$ D. schauinslandii s. ampl., $11 \%$ D. sp. aff. D. crux darwinii, $2 \%$ M. apiculata s. ampl., $1 \%$ Distephanus speculum speculum, and $<1 \%$ D. sp. cf. $D$. longispinus.

Site 343 (lat $68^{\circ} 42.91^{\prime} \mathrm{N}$, long $5^{\circ} 45.73^{\prime} \mathrm{E}$, depth $3131 \mathrm{~m}$ )

A Quaternary Gephyrocapsa oceanica Zone coccolith assemblage containing Gephyrocapsa caribbeanica and $G$. oceanica is present in Core $2(5 \mathrm{~m})$. The only other coccolith-bearing sample examined, from Core 8 (215 m), contains a lower Eocene, probable Tribrachiatus orthostylus Zone assemblage, based on quadrate Imperiaster sp. aff. I. obscurus, Syracosphaera sp. cf. $S$. fimbriata and Zygolithus dubius. Quadrate $I$. sp. aff. $I$. obscurus is associated with the T. orthostylus Zone in the North Atlantic (Bukry, 1972). Additional evidence for this zonal assignment comes from Core AS 1-9 at lat $66^{\circ} 21^{\prime} \mathrm{N}$., long $00^{\circ} 18^{\prime} \mathrm{E}$., which was kindly provided by Tsune Saito (see Saito et al., 1967). Two samples from this core at $295 \mathrm{~cm}$ and $310 \mathrm{~cm}$ contain the coccoliths Chiasmolithus grandis, Imperiaster obscurus, $I$. sp. aff. $I$. obscurus, Syracosphaera fimbriata, Transversopontis pulchra, Tribrachiatus orthostylus, Zygolithus dubius, and a few reworked Paleocene taxa.

Sample $343-5-3,75-76 \mathrm{~cm}(148 \mathrm{~m})$ contains the first reported specimens of the silicoflagellates Dictyocha rotundata secta and Distephanus antiquus from DSDP cores. Originally described from the upper Eocene or Oligocene of the USSR (Glezer, 1966), these species are present with Dictyocha spinosa and Naviculopsis foliacea, which indicate a probable middle Eocene lower Dictyocha hexacantha Zone assignment at Site 343. The assemblage, based on a count of 300 specimens, includes: $49 \%$ D. rotundata secta, $18 \%$ D. sp. (asperoid), 9\% Distephanus sp. aff. D. speculum pentagonus (large, no basal pikes), $7 \%$ Naviculopsis foliacea, $7 \%$ Dictyocha spinosa, $5 \%$ Corbisema apiculata, $2 \%$ Distephanus antiquus, and $<1 \%$ or $1 \%$ each of Corbisema sp. cf. C. hastata minor, C. ovalis, Cannopilus sp. aff. C. schulzii, Dictyocha frenguellii s. str., Mesocena oamaruensis, and Naviculopsis nordica nordica.

Site 344 (lat $76^{\circ} 08.98^{\prime} \mathrm{N}$, long $7^{\circ} 52.52 ' \mathrm{E}$, depth $2156 \mathrm{~m}$ )

Coccoliths are rare and nondiagnostic in samples examined from Site 344 . No silicoflagellates were observed.

Site 345 (lat $69^{\circ} 50.23^{\prime} \mathrm{N}$, long $1^{\circ} 14.26^{\prime} \mathrm{W}$, depth $3195 \mathrm{~m}$ )

Quaternary coccolith assemblages indicated by Gephyrocapsa caribbeanica and containing admixed Cretaceous taxa are present in samples from Cores 1 to $4(0$ to $37 \mathrm{~m})$. Rare silicoflagellates in Core 7 , including Naviculopsis navicula s. str., $N$. quadrata, Mesocena apiculata curvata, and Distephanus speculum hemisphaericus suggest lower Miocene, if they are in place. Deeper samples examined from Cores 8 to 25 ( 94 to $83 \mathrm{~m})$ are barren of these fossils.

Site 346 (lat $69^{\circ} 53.35^{\prime} \mathrm{N}$, long $8^{\circ} 41.14^{\prime} \mathrm{W}$, depth $732 \mathrm{~m}$ )

The shallowest sample examined, 346-4-2, 130-131 $\mathrm{cm}(27 \mathrm{~m})$, contains rare small Gephyrocapsa $\mathrm{sp}$. and reworked Cretaceous coccoliths; a Quaternary age is assigned. Miocene silicoflagellates are rare in Cores 5 and 11 , otherwise samples from this site proved barren.

The lower or middle Miocene Corbisema triacantha Zone is suggested for Sample 346-5-3, 146-147 cm (40 $\mathrm{m})$, by the predominance of Corbisema triacantha and Distephanus speculum hemisphaericus over the associated specimens which include Distephanus crux crux, $D$. sp. cf. D. longispinus, and Mesocena apiculata curvata.

The upper Oligocene or lower Miocene acme of Distephanus crux darwinii and D. raupii, which is present in southern high latitudes (Bukry, in press), is indicated in Sample 346-11-3, 90-91 cm (95 m), by $80 \%$ domination of these two species over associated taxa including $12 \%$ Distephanus crux crux, and $2 \%$ each of $D$. speculum hemisphaericus, Cannopilus schulzii, C. sp., and Mesocena apiculata curvata, based on a count of 50 specimens.

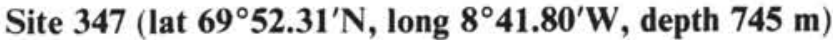

The single sample examined, 347-1-2, 145-146 cm (2 $\mathrm{m})$, contains a Coccolithus ooze. A Quaternary age is assigned based on the occurrence of Coccolithus neohelis, C. pelagicus, and C. pliopelagicus.

\section{Site 348 (lat $68^{\circ} 30.18^{\prime} \mathrm{N}$, long $12^{\circ} 27.72^{\prime} \mathrm{W}$, depth $1763 \mathrm{~m}$ )}

Half of the 16 samples provided from Site 348 are barren. Quaternary coccolith assemblages from Cores 1 and 2 (0 to $19 \mathrm{~m})$ contain Crenalithus productellus, Gephyrocapsa sp. cf. G. aperta, G. caribbeanica, and reworked Cretaceous specimens, such as Prediscosphaera cretacea.

The best silicoflagellate samples from Core 12 and 15 indicate upper Miocene or lower Pliocene and middle Miocene, respectively. Sample 348-12-3, 140-141 cm $(165 \mathrm{~m})$ is dominated by pentagonal Distephanus boliviensis boliviensis, but also contains a few $D$. 
schauinslandii s. ampl., Mesocena circulus and $M$. diodon, which, together, suggest lower Pliocene, based on assemblages from the Antarctic area (Ciesielski, 1975). A broader age range is chosen because the translatitudinal correlations of Subarctic to Antarctic fossil ranges is still not well known for silicoflagellates.

Sample $348-15-3,130-131 \mathrm{~cm}(213 \mathrm{~m})$ is dominated by long-spined forms of Distephanus schauinslandii s. ampl. Percentages of species based on a count of 300 specimens are: $57 \%$ Distephanus schauinslandii (major spines elongate), $15 \%$ Cannopilus ernestinae s. str., $10 \%$ Mesocena apiculata curvata (all isosceles; $8 \%$ concave, $2 \%$ straight or convex basal side), $7 \%$ Distephanus crux crux (large; $1 \%$ are asperoid, fibuloid, and medusoid variants), $4 \% D$. schauinslandii (equant spines), $2 \% D$. longispinus, $2 \%$ Cannopilus sp., $1 \%$ Distephanus speculum speculum, $<1 \%$ D. speculum binoculus, $<1 \%$ Mesocena diodon. This assemblage resembles those of Cores 8 and 9 at Site 338; and although relative silicoflagellate abundances differ, lithologies are very similar. The association of $C$. ernestinae with $M$. apiculata s. ampl. in middle Miocene siliceous ooze from the Antarctic area (Bukry, in press) suggests the tentative middle Miocene assignment at Site 348.

\section{Site 329 (lat $69^{\circ} 12.41^{\prime} \mathrm{N}$, long $8^{\circ} 05.80^{\prime} \mathrm{W}$, depth $915 \mathrm{~m}$ )}

Of five samples examined from this site, only two contained any coccoliths. Core $1(0$ to $6 \mathrm{~m})$ has a sparse Quaternary assemblage admixed with reworked Cretaceous. Core $6(120$ to $130 \mathrm{~m})$ contains sparse Reticulofenestra umbilica which has a middle Eocene to lower Oligocene range, if in place.

\section{Site 350 (lat $67^{\circ} 03.34^{\prime} \mathrm{N}$, long $8^{\circ} 17.68^{\prime} \mathrm{W}$, depth $1275 \mathrm{~m}$ )}

Four samples from Cores 1 to 8 ( 0 to $208 \mathrm{~m}$ ) are barren.

\section{Site 352 (lat $63^{\circ} 38.97^{\prime} \mathrm{N}$, long $12^{\circ} 28.26^{\prime} \mathrm{W}$, depth $990 \mathrm{~m}$ )}

No samples.

\section{SILICOFLAGELLATE TAXONOMY}

Owing to space limitations for Volume 38, only new or rarely cited taxa and new combinations are treated in this initial report. See other Deep Sea Drilling Project volumes for more complete taxonomies.

\section{Genus CORBISEMA Hanna, 1928 \\ Corbisema katharinae n. sp. \\ (Plate 1, Figures 1-6)}

?Corbisema cf. C. lamellifera hastata (Glezer) Perch-Nielsen, 1975, p. 685 , pl. 3 , fig. 18 .

Description: Corbisema katharinae has a lobed, irregular isosceles basal ring. The radial spines are short and straight, but the basal pikes are long and curved. The apical struts broaden toward the center forming a triangular plate-like area. The irregular outline of the basal ring, together with the more regular form of the apical structure, produces three dissimilarly shaped portals.

Remarks: Corbisema katharinae is distinguished from the $C$. hastata group by irregular outline and broadened apical structure, and from $C$. lamellifera, $C$. recta, and $C$. schulzii by the tubular instead of flattened form of its basal ring. The specimens from Leg 38 differ from C. cf. C. lamellifera hastata of Leg 29 by the tubular form of the basal pikes.

Occurrence: Corbisema katharinae is common in upper Eocene or Oligocene Cores 9 and 10 at Site 337 .

Size: Basal-ring height $25-50 \mu \mathrm{m}$.
Holotype: USNM 236055 (Plate 1, Figure 4).

Isotypes: USNM 236056 to 236059.

Type locality: Norwegian-Greenland Sea, Sample 337-10-6, 62-64 $\mathrm{cm}(93 \mathrm{~m})$.

\section{Corbisema ovalis Perch-Nielsen}

Corbisema ovalis Perch-Nielsen, 1976, p. 33, figs 12, 13, and 23.

Remarks: This moderately large species, having three broad regular lobes, is easily distinguished by the radial spines which are directed downward out of the plane of the basal ring.

\section{Genus DICTYOCHA Ehrenberg, 1837}

Dictyocha rotundata secta Glezer

(Plate 1, Figures 7-10)

Dictyocha rotundata var. secta Glezer, 1962, p. 152, fig. 5a-k.

Remarks: This unusual taxon was well illustrated by Glezer, but may easily be overlooked because of its shape and small size. Because it is small, short-spined, and is as high as wide, it is commonly seen in side views. Dictyocha rotundata secta is abundant in an Eocene sample from Site 343.

\section{Genus DISTEPHANUS Stöhr, 1880 \\ Distephanus antiquus Glezer \\ (Plate 1, Figures 11, 12)}

Distepanus antiquus Glezer, 1964, p. 57, pl. 2, fig. 6-9.

Distephanus sp. aff. D. crux crux (Ehrenberg)

Distephanus crux (Ehrenberg), Locker, 1974 (in part), p. 637, pl. 3, fig. 8 .

Remarks: Specimens that resemble Distephanus crux var. parva of Bachmann (1971), but that lack basal pikes, are listed as $D$. aff. crux crux (1). Specimens tabulated from Site 338 that have a moderately large apical ring, regular lobed outline, moderate spines, but that lack basal pikes are listed as Distephanus aff. crux crux (2).

\section{Distephanus crux darwinii Bukry}

(Plate 1, Figures 13, 14)

Distephanus crux darwinii Bukry, in press a, p. 895, pl. 7, fig. 4-13 Remarks: Specimens of Distephanus crux darwinii at Site 338 are similar to those from the South Atlantic. Specimens that have slightly larger apical and basal rings, however, are common and are tabulated as Distephanus sp. aff. D. crux darwinii; like D. crux darwinii they lack basal pikes.

\section{Distephanus norvegiensis Perch-Nielsen}

(Plate 1, Figure 15)

Distephanus norvegiensis Perch-Nielsen, in press b, p. 34, figs. 15, 16, and 20.

Distephanus pseudofibula (Schulz) n. comb.

Dictyocha speculum f. pseudofibula Schulz, 1928, p. 262, fig. 51a, b.

\section{Distephanus raupii Bukry \\ (Plate 1, Figures 16-18)}

Distephanus raupii Bukry, in press a, p. 895, pl. 7, fig. 14, 15.

Remarks: Oligocene and Miocene Distephanus raupii from Leg 38 have similar size ranges and proportions to those from the South Atlantic and Subantarctic. Larger, longer spined specimens from the Eocene at Site 337 are tabulated as Distephanus raupii s. ampl.

Distephanus speculum giganteus $\mathbf{n}$. subsp.

(Plate 1, Figure 19; Plate 2, Figures 1, 2)

Description: Distephanus speculum giganteus has a large hexagonal basal ring with straight or slightly convex sides. Basal pikes are small, knob-like, and offset from the strut junctions; one pair of spines is distinctly longer than the other two. The apical ring is large and rounded, its diameter is only slightly less than the basal ring.

Remarks: Distephanus speculum giganteus is distinguished from D. speculum minuta by being two to three times larger ( 90 to $100 \mu \mathrm{m}$ maximum length compared to 35-56 $\mu \mathrm{m}$ ) and by having a more elongate basal ring. Because of its large apical ring, D. speculum 
giganteus may bear the same phenotypic relation to $D$. boliviensis boliviensis that $D$. speculum minuta bears to $D$. speculum speculum. However, its elongate form prompts its initial classification in the $D$. speculum group.

Occurrence: Distephanus speculum giganteus is associated with other large taxa such as the $D$. boliviensis and $D$. schauinslandii groups in Sample 338-10-2, 130-132 cm (97 m) which is assigned to the middle Miocene. It is missing from other samples examined from Leg 38.

Size: Length 90-100 $\mu \mathrm{m}$, inner diameter 30-40 $\mu \mathrm{m}$.

Holotype: USNM 236060 (Plate 2, Figure 1).

Isotypes: USNM 236061 and 236062.

Type locality: Norwegian-Greenland Sea, Sample 338-10-2, 130$132 \mathrm{~cm}(97 \mathrm{~m})$.

\section{Distephanus varians (Gran and Braarud) n. comb.}

Distephanus speculum f. varians Gran and Braarud, 1935, p. 390, fig. $68 \mathrm{~A}, \mathrm{~B}$.

Remarks: Distephanus varians could be considered a junior synonym of D. pseudofibula (Ling, 1972; Bukry, in press a); however, observed differences in their relative percentages from sample to sample and area to area suggest a potential value in continuing the distinction.

\section{Genus MESOCENA Ehrenberg, 1843}

Mesocena apiculata curvata n. subsp.

(Plate 2, Figures 15, 16)

Septamesocena apiculata (Schulz), Perch-Nielsen, 1975 (in part), p. 689 , pl. 10 , fig. 6 .

Mesocena apiculata (Schulz), Bukry, 1975 (in part), p. 856, pl. 5, fig. 7 .

Description: Mesocena apiculata curvata has a triangular basal ring, isosceles in form, and having, usually, one side that is concave. Spines are moderate to short and septate.

Remarks: Mesocena apiculata curvata is distinguished from $M$. apiculata apiculata (Schulz, 1928) by having isosceles form and usually one concave side. It is distinguished from $M$. oamaruensis by spines and a more isosceles form. A triconcave variation, Mesocena sp. cf. M. apiculata curvata, was noted only in $338-22-6,84-85 \mathrm{~cm}(217 \mathrm{~m})$ (see Plate 2, Figure 17).

Occurrence: Mesocena apiculata curvata is most common in the lower and middle Miocene where it may dominate $M$. apiculata apiculata. It appears to have evolved from the equilateral $M$. apiculata apiculata of the upper Eocene and Oligocene.

Size: Basal-ring height $50-70 \mu \mathrm{m}$.

Holotype: USNM 236063 (Plate 2, Figure 15).

Isotypes: USNM 236064 and 236065.

Type locality: Norwegian-Greenland Sea, Sample 346-5-3, 146$147 \mathrm{~cm}(40 \mathrm{~m})$.

\section{Genus NAVICULOPSIS Frenguelli, 1940 \\ Naviculopsis foliacea Deflandre \\ (Plate 2, Figure 11)}

Naviculopsis foliacea Deflandre, 1950, p. 204, fig. 235-240.

Remarks: Naviculopsis foliacea has distinctly larger portals than N. nordica nordica.

\section{Naviculopsis nordica n. sp. \\ (Plate 2, Figures 12-14)}

Description: Naviculopsis nordica has a narrow elongate basal ring. The spines are shorter than the basal ring and form a nearly continuous line with the ring outline. The apical plate has two small perforations at the ends of the basal ring. The perforations are circular or elongate and canted such that one long side may be bounded by the ring and the other lie within the plate.

Remarks: Naviculopsis nordica is distinguished from $N$. nordica hyalina by the small perforations at the ends of the apical plate. It is distinguished from $N$. foliacea by the distinctly smaller size of its perforations compared to the portals of $N$. foliacea. The length of the perforations of $N$. nordica occupy only $3 \%$ to $11 \%$ of the length of the basal ring, whereas the length of the portals of $N$. foliacea occupy $26 \%$ to $42 \%$ (see Deflandre, 1950; Ling, 1972; Dumitrica, 1973; Bukry, 1973; and Perch-Nielsen, 1975).

Occurrence: Naviculopsis nordica is rare to common in middle or upper Eocene samples from Cores 3 to 11 at Site 340 and Core 5 at Site 343.
Size: Basal-ring length $70-85 \mu \mathrm{m}$.

Holotype: USNM 236069 (Plate 2, Figure 12).

Isotypes: USNM 236070 and 236071.

Type locality: Norwegian-Greenland Sea, Sample 340-11-6, 40-41 $\mathrm{cm}(102 \mathrm{~m})$.

\section{Naviculopsis nordica hyalina n. subsp.}

\author{
(Plate 2, Figures 8-10)
}

Description: Naviculopsis nordica hyalina has a narrow elongate basal ring. The spines are shorter than the basal ring and form a continuous line with the ring outline. The apical plate is imperforate filling the entire inner area of the basal ring.

Remarks: Naviculopsis nordica hyalina is distinguished from $N$. nordica nordica by having an imperforate plate. It is distinguished from $N$. foliacea by its narrower tapering basal ring and unflexed outline where the spines and basal ring join.

Occurrence: Naviculopsis nordica hyalina is known only from the middle or upper Eocene of Cores 3 to 11 at Site 340.

Size: Basal-ring length $70-85 \mu \mathrm{m}$.

Holotype: USNM 236066 (Plate 2, Figure 10).

Isotypes: USNM 236067 and 236068.

Type locality: Norwegian-Greenland Sea, Sample 340-7-6, 50-51 $\mathrm{cm}(65 \mathrm{~m})$.

\section{Naviculopsis punctilia punctilia Perch-Nielsen (Plate 2, Figure 3)}

Naviculopsis punctilia Perch-Nielsen, 1976, p. 36, figs. 1 and 32.

$$
\text { Naviculopsis punctilia taenia n. subsp. }
$$$$
\text { (Plate 2, Figures 4-7) }
$$

Description: Naviculopsis punctilia taenia has long spines that are approximately equal to the basal ring which is parallel-sided or slightly convex. The elevated apical plate occupies a third, or less, of the basal ring and borders one side of the two large portals. Two additional smaller portals occur at the minor axis of the basal ring where the plate joins the ring. This creates an X-shaped apical plate.

Remarks: Depending on the relative sizes of the lamellar apical structures and the basal ring, different specimens of Naviculopsis punctilia taenia can resemble $N$. constricta, N. foliacea, or N. punctilia punctilia. It is distinguished from all of these by the combined presence of an apical plate and side portals.

Occurrence: Naviculopsis punctilia taenia occurs with a diverse suite of Naviculopsis species in middle or upper Eocene Cores 3 to 11 at Site 340 .

Size: Basal-ring length $50-75 \mu \mathrm{m}$.

Holotype: USNM 236072 (Plate 2, Figure 5).

Isotypes: USNM 236073 to 236075.

Type locality: Norwegian-Greenland Sea, Sample 340-3-3, 40-41 $\mathrm{cm}(22 \mathrm{~m})$.

\author{
Naviculopsis vemae Perch-Nielsen \\ Naviculopsis vemae Perch-Nielsen, 1976, p. 36, figs. 3, 4, and 18.
}

\section{REFERENCES}

Bachmann, A., 1971. Silicoflagellaten aus dem Eggenburgien von Ernstbrunn (Niederösterreich): Osterreichische Geol. Bundesanst. Verh., v. 3, p. 552-569.

Bukry, D., 1972. Further comments on coccolith stratigraphy, Leg 12, Deep Sea Drilling Project. In Berggren, W.A., Laughton, A.S., et al., Initial Reports of the Deep Sea Drilling Project, Volume 12: Washington (U.S. Government Printing Office), p. 1071-1083.

, 1973. Coccolith and silicoflagellate stratigraphy, Tasman Sea and southwestern Pacific Ocean, Deep Sea Drilling Project Leg 21. In Bruns, R.E., Andrews, J.E., et al., Initial Reports of the Deep Sea Drilling Project, Volume 21: Washington (U.S. Government Printing Office), p. 885-893.

1975. Silicoflagellate and coccolith stratigraphy, Deep Sea Drilling Project Leg 29. In Kennett, J.P., Houtz, R.E., et al., Initial Reports of the Deep Sea Drilling Proj- 
ect, Volume 29: Washington (U.S. Government Printing Office), p. 845-872.

in press (a). Cenozoic silicoflagellate and coccolith stratigraphy, South Atlantic Ocean, Deep Sea Drilling Project Leg 36. In Hollister, C. D., Craddock, C. et al., Initial Reports of the Deep Sea Drilling Project, Volume 35: Washington (U.S. Government Printing Office).

, in press (b). Comments on some coccoliths and silicoflagellates from Deep Sea Drilling Project Leg 35. In Craddock, C., Hollister, C.D., et al., Initial Reports of the Deep Sea Drilling Project, Volume 35: Washington (U.S. Government Printing Office).

Ciesielski, P.F., 1975. Biostratigraphy and paleoecology of Neogene and Oligocene silicoflagellates from cores recovered during Antarctic Leg 28, Deep Sea Drilling Project. In Hayes, D., Frakes, L.A., et al., Initial Reports of the Deep Sea Drilling Project, Volume 28: Washington (U.S. Government Printing Office), p. 625-691.

Deflandre, G., 1950. Contribution a l'étude des silicoflagellidés actuels et fossiles: Microscopie, v. 2, p. 72-108, 117-142, and 191-210.

Dumitrica, P., 1973. Paleocene, late Oligocene and postOligocene silicoflagellates in southwestern Pacific sediments cored on DSDP Leg 21. In Burns, R.E., Andrews, J.E., et al., Initial Reports of the Deep Sea Drilling Project, Volume 21: Washington (U.S. Government Printing Office), p. 837-883.

Glezer, Z.I., 1962. K voprosu o filogeneze kremnevykh zhgutikovykh vodorosley (On the phylogeny of silicoflagellates): Paleont. Zhur. 1962, no. 1, p. 146-156. 1964. Novye kremnevye zhgutikovye vodorosli Paleogena SSSR (New silicoflagellates from the Paleogene of the USSR): Akad. Nauk SSSR, Novosti sistematiki nizshikh rasteniy, otdel. ottisk, p. 46-58.

1966. Silicoflagellatophyceae. In Gollerbakh, M.M. (Ed.), Cryptogamic plants of the U.S.S.R.: Akad.
Nauk SSSR, V.A. Komarova Bot. Inst. (Translated from Russian by Israel Program for Scientific Translations Ltd., Jerusalem, 1970), v. 7, p. 1-363.

Gran, H.H. and Braarud, T., 1935. A quantitative study of the phytoplankton in the Bay of Fundy and the Gulf of Maine (including observations on hydrography, chemistry and turbidity): Biol. Board Canada, v. 1, p. 280-467.

Ling, H.Y., 1972. Upper Cretaceous and Cenozoic silicoflagellates and ebridians: Am. Paleontol. Bull., v. 62, p. $135-229$.

Locker, S., 1974. Revision der Silicoflagellaten aus der Mikrogeologischen Sammlung von C.G. Ehrenberg: Ecolog. Geol. Helv., v. 67, p. 631-646.

Martini, E., 1972. Silicoflagellate zones in the late Oligocene and early Miocene of Europe: Senckenberg. Lethaea, v. 53 , p. $119-122$.

1974. Silicoflagellate zones in the Eocene and early Oligocene: Senckenberg. Lethaea, v. 54, p. 527-532.

Perch-Nielsen, K., 1975. Late Cretaceous to Pleistocene silicoflagellates from the southern southwest Pacific, DSDP Leg 29. In Kennett, J.P., Houtz, R.E., et al., Initial Reports of the Deep Sea Drilling Project, Volume 29: Washington (U.S. Government Printing Office), p. 677 721.

1976. New silicoflagellates and a silicoflagellate zonation in north European Paleocene and Eocene diatomites: Geol. Soc. Denmark Bull., v. 25, p. 27-40.

Saito, T., Burckle, L..H., and Horn, D.R., 1967. Palaeocene core from the Norwegian Basin: Nature, v. 216, p. 357359.

Sanfilippo, A., Burckle, L.H., Martini, E., and Riedel, W.R., 1973. Radiolarians, diatoms, silicoflagellates and calcareous nannofossils in the Mediterranean Neogene: Micropaleontology, v. 19, p. 209-234.

Schulz, P., 1928. Beiträge zur Kenntnis fossiler und rezenter Silicoflagellaten: Bot. Archiv, v. 21, p. 225-292. 



\section{PLATE 1}

Silicoflagellates from DSDP Leg 38.

Figures 1-6, 11-16, and 19 magnification $800 \times$; scale bar equals $10 \mu \mathrm{m}$

Figures $7-10,17$, and 18 magnification $1100 \times$; scale bar equals $10 \mu \mathrm{m}$.

Figures 1-6 Corbisema katharinae n. sp.

All specimens from Sample 337-10-6, 62-64 cm (93

$\mathrm{m})$.

1. USNM 236056.

2. USNM 236057.

3. USNM 236058.

4. Holotype, USNM 236055

5, 6. USNM 236059, apical and basal focuses.

Figures 7-10 Dictyocha rotundata secta Glezer.

All specimens from Sample 343-5-3, 75-76 cm (148 $\mathrm{m})$.

7, 8. Same specimen, basal and apical focuses.

9, 10. Same specimen, basal and apical focuses.

Figures 11, 12 Distephanus antiquus Glezer.

Sample 343-5-3, 75-76 cm (148 m).

Same specimen, basal and apical focuses.

Figures 13, 14 Distephanus crux darwinii Bukry.

13. Sample $338-23-3,119-120 \mathrm{~cm}(223 \mathrm{~m})$.

14. Sample 337-10-6, 62-64 cm (93 m).

Figure 15 Distephanus norvegiensis Perch-Nielsen.

Binoculoid specimen, Sample 340-2-3, 60-61 cm $(13 \mathrm{~m})$.

Figures 16-18 Distephanus raupii Bukry.

16. Sample 337-10-6, $62-64 \mathrm{~cm}(93 \mathrm{~m})$.

17, 18. Sample $338-23-3,119-120 \mathrm{~cm}(223 \mathrm{~m})$, basal and apical focuses.

Figure 19 Distephanus speculum giganteus n. subsp.

USNM 236061, Sample 338-10-2, 130-132 cm (97 $\mathrm{m})$. 
PLATE 1
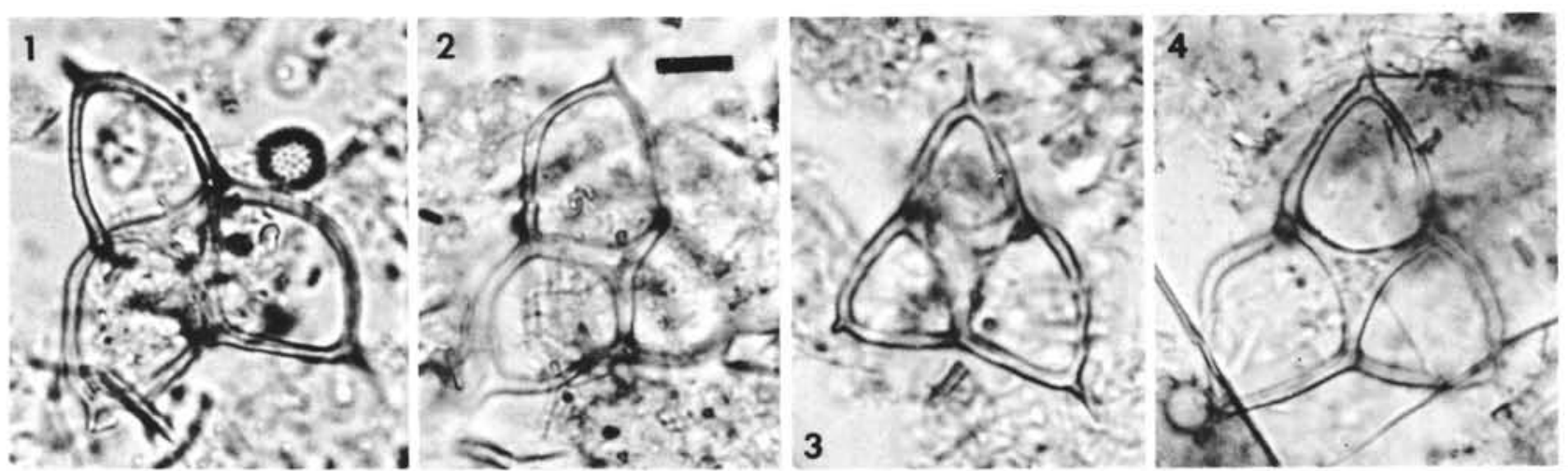

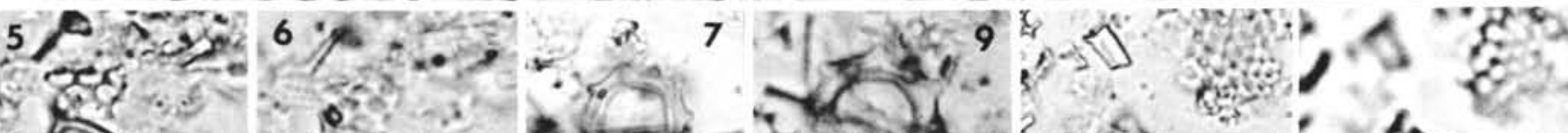

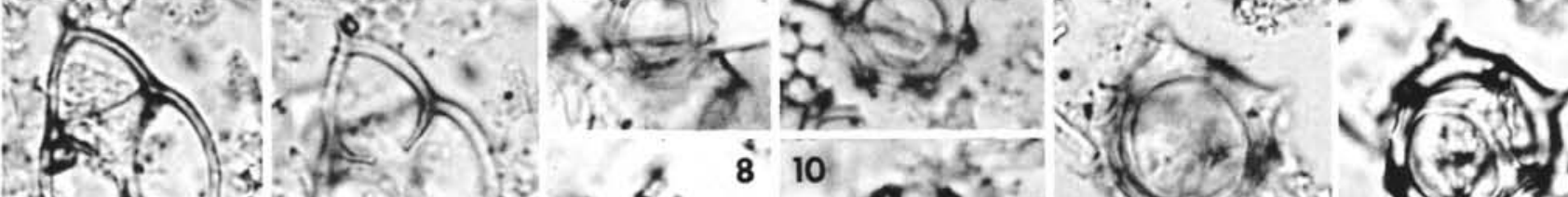

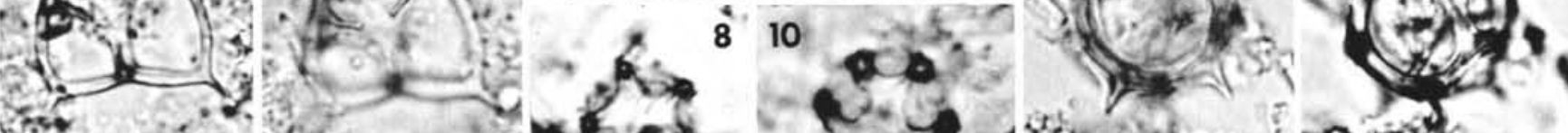

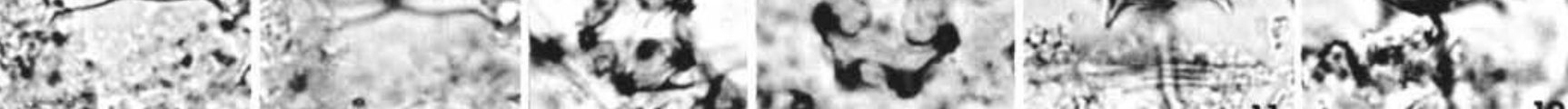

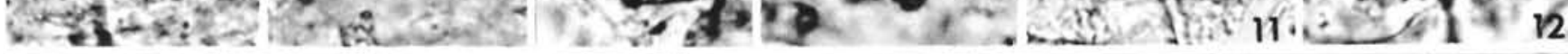
(2)
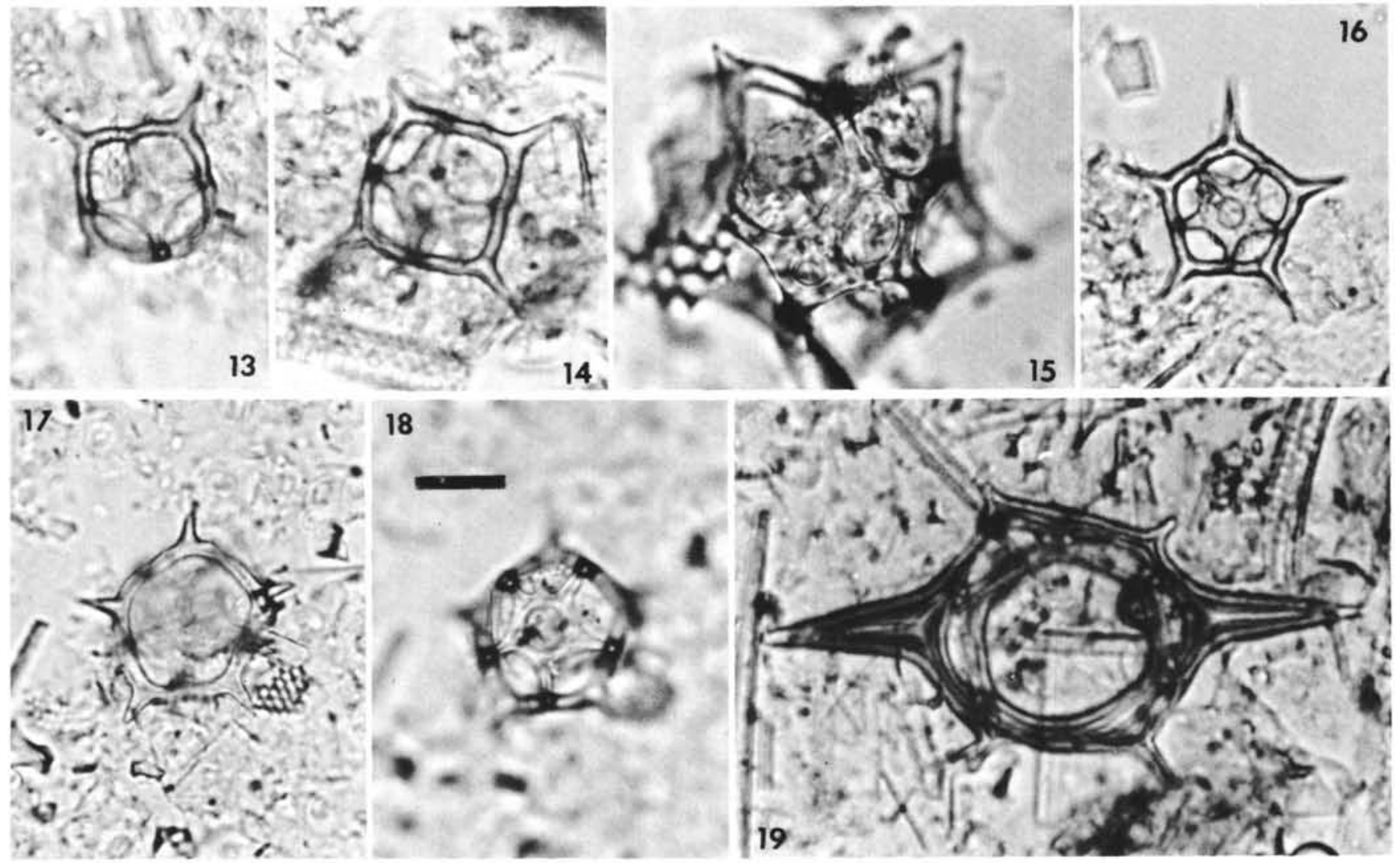


\section{PLATE 2}

Silicoflagellates from DSDP Leg 38.

All figures same magnification; scale bar equals $10 \mu \mathrm{m}$.

Figures 1,2 Distephanus speculum giganteus n. subsp.

1. Holotype, USNM 236060, Sample 338-10-2, $130-132 \mathrm{~cm}(97 \mathrm{~m})$.

2. USNM 236062, Sample 338-10-2, 130-132 cm $(97 \mathrm{~m})$.

Figure $3 \quad$ Naviculopsis punctilia punctilia Perch-Nielsen. Sample 340-3-3, 40-41 cm (22 m).

Figures 4-7 Naviculopsis punctilia taenia n. subsp.

4. USNM 236073 , Sample $340-3-3,40-41 \mathrm{~cm}(22$ $\mathrm{m})$.

5. Holotype, USNM 236072, Sample 340-3-3, $40-41 \mathrm{~cm}(22 \mathrm{~m})$.

6. USNM 236074, Sample 340-7-6, 50-51 cm (65 $\mathrm{m})$.

7. USNM 236075 , Sample $340-7-6,50-51 \mathrm{~cm} \mathrm{(65}$ $\mathrm{m})$.

Figures 8-10 Naviculopsis nordica hyalina n. subsp.

All specimens from Sample 340-7-6, 50-51 cm (65 $\mathrm{m})$.

8. USNM 236067.

9. USNM 236068.

10. Holotype, USNM 236066.

Figure $11 \quad$ Naviculopsis foliacea Deflandre. Sample 343-5-3, 75-76 cm (148 m).

Figures 12-14 Naviculopsis nordica $\mathrm{n}$. sp.

12. Holotype, USNM 236069, Sample 340-11-6, $40-41 \mathrm{~cm}(102 \mathrm{~m})$.

13. USNM 236070 , Sample $340-3-3,40-41 \mathrm{~cm}(22$ $\mathrm{m})$.

14. USNM 236071, Sample 340-7-6, 50-51 cm (65 $\mathrm{m})$.

Figures 15,16 Mesocena apiculata curvata $\mathrm{n}$. subsp.

15. Holotype, USNM 236063, Sample 346-5-3, $146-147 \mathrm{~cm}(40 \mathrm{~m})$.

16. USNM 236064, Sample 338-12-3, 60-61 cm $(116 \mathrm{~m})$.

Figure 17 Mesocena sp. cf. M. apiculata curvata n. subsp. USNM 236065, Sample 338-22-6, 84-85 cm (217 $\mathrm{m})$. 
PLATE 2
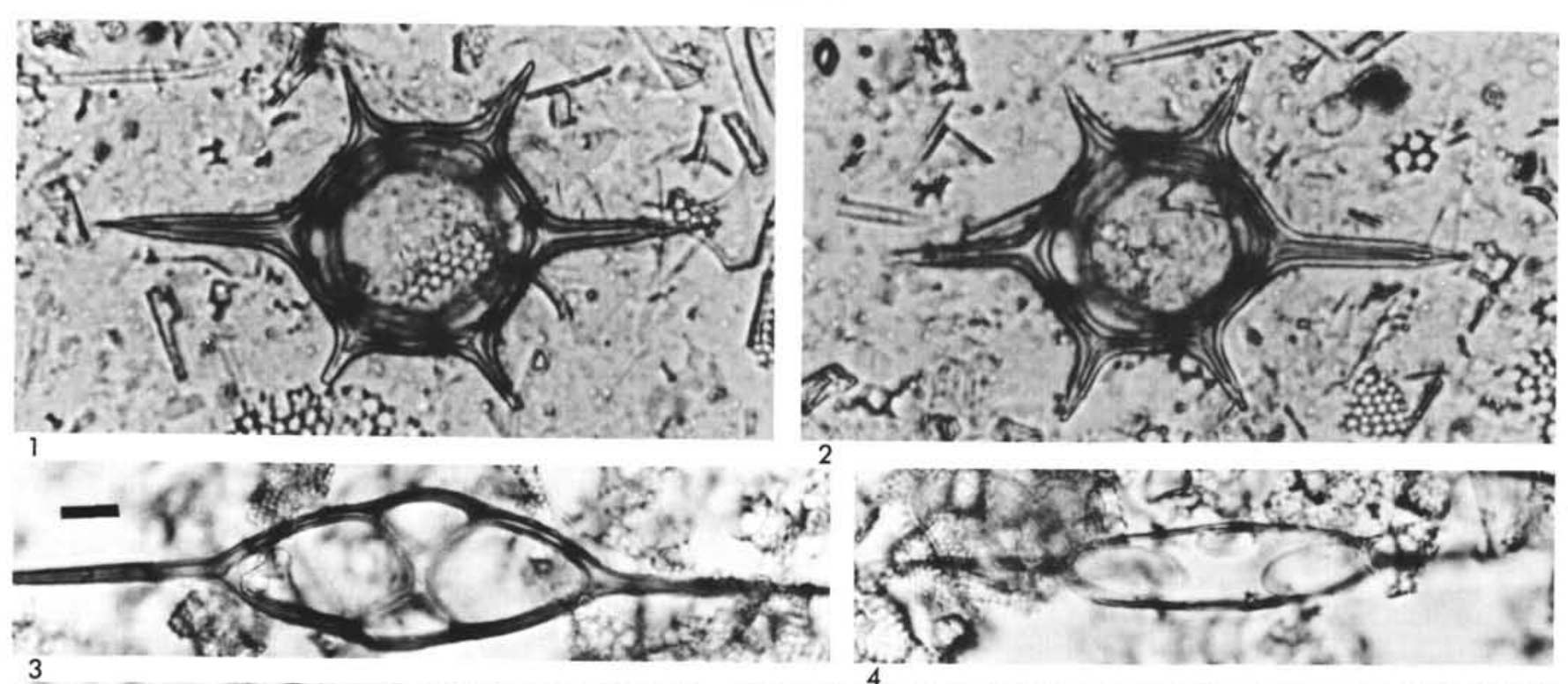

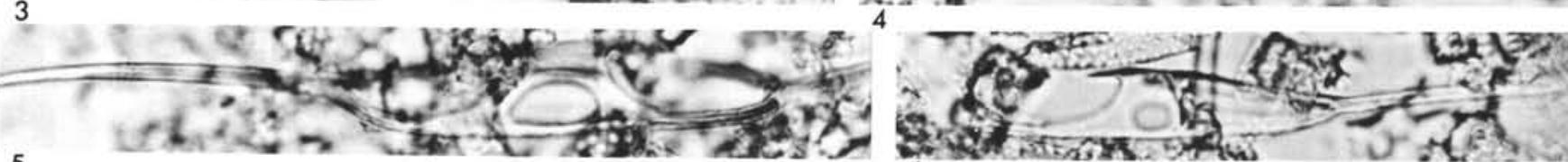
5 The

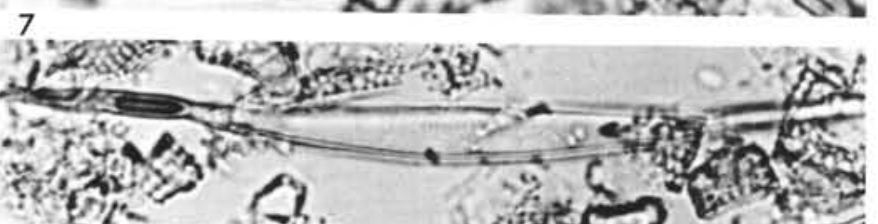
9

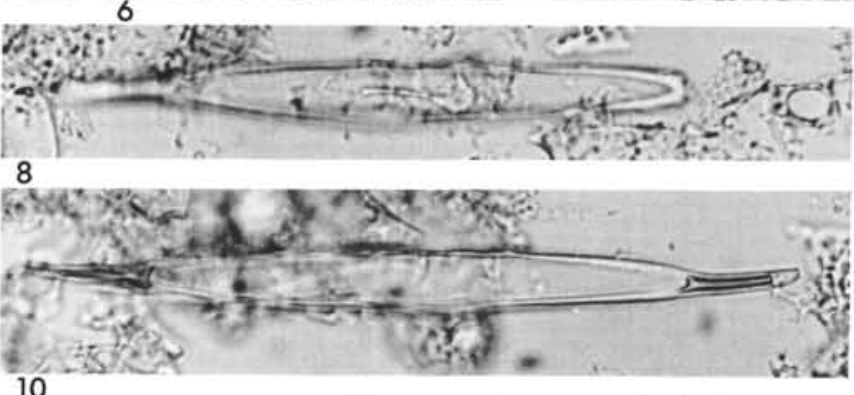
Sis
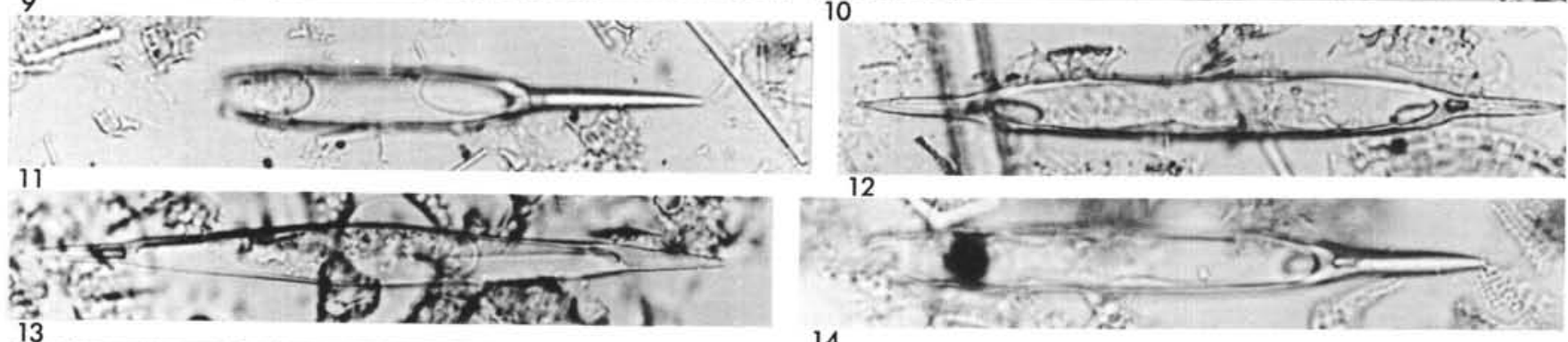

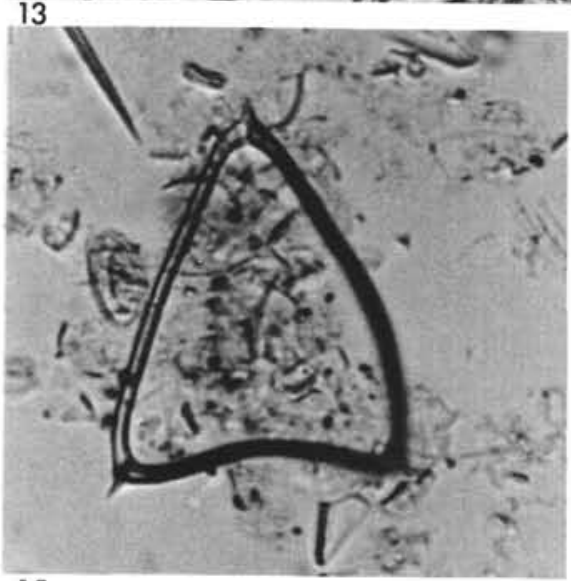

15

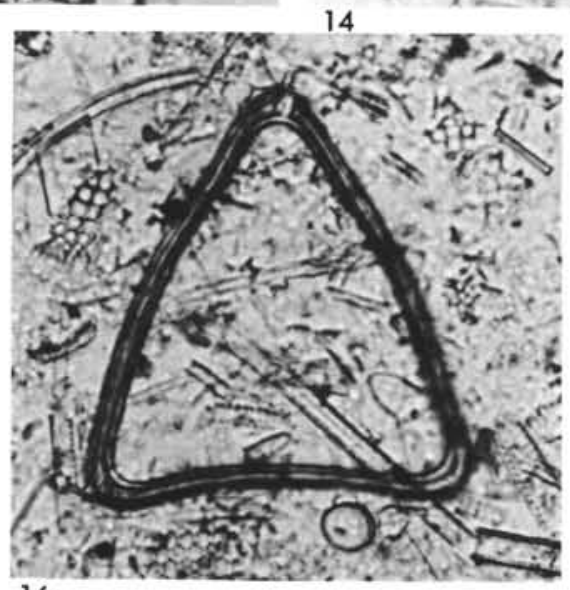
16

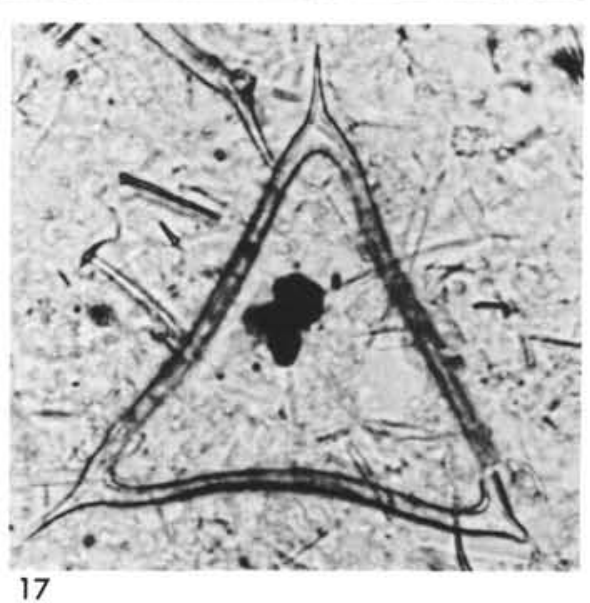

